\title{
CHEMICAL STUDIES ON BACTERIAL AGGLUTINATION
}

\section{Quantitative Data on Pneumococcus R (Dawson S)- Anti-R (S) Systems*}

By MiChael heidelberger, Рн.D., and Elvin A. KABAT, Ph.D.

(From the Departments of Medicine and Biological Chemistry, College of Physicians and Surgeons, Columbia University, and the Presbyterian Hospital, New York)

(Received for publication, January 24, 1938)

Antisera produced in rabbits by injection of pneumococcus in the $R$ phase, or S phase as it has been termed by Dawson (1), have been examined mainly for their protective power (2). Since this proved to be low against the virulent $S$ phase (Dawson $M$ ) little more has been recorded. However, in a study of an absolute, quantitative method for the estimation of agglutinins (3) it was found that accurate results could be obtained with pneumococcus $\mathrm{R}$ (Dawson S) as well as with the $M$ phase $(3,4)$. The behavior of a number of anti-R (S) sera was studied with suspensions of acid-killed, heat-killed, and formalinized $R(S)$ pneumococci, and quantitative precipitin estimations were also made with pneumococcus $\mathrm{C}$ substance (5). Relationships brought to light by this study are recorded in the present paper.

\section{EXPERIMENTAI}

Stock pneumococcus (Pn) Type I strain $192 \mathrm{R}(\mathrm{S})$ and Type II strain D $39 \mathrm{R}$ (S) cultures were used. 5 to 10 liter lots were grown in meat infusion broth and were centrifuged off and killed either by acidification to $\mathrm{pH} 4$ (designated $\mathrm{Pn} \mathrm{AK}$ below), by heating to $60^{\circ} \mathrm{C}$. for 0.75 hour (HK), or by letting stand at room temperature overnight with 1 per cent formalin (FK). The cells were centrifuged, washed with saline until appreciable quantities of nitrogen could no longer be detected in the supernatant, and diluted with saline containing $1: 10,000$ merthiolate ${ }^{2}$ until the nitrogen content equalled 0.10 to $0.15 \mathrm{mg}$. per $\mathrm{ml}$. Rabbits were

* The work reported in this communication was carried out under the Harkness Research Fund of the Presbyterian Hospital.

1 These cultures were kindly furnished by Dr. Martin H. Dawson of this department.

2 Manufactured by Eli Lilly and Company, Indianapolis, Indiana. 
injected intravenously four times weekly for a period of 4 weeks with 1 to $4 \mathrm{ml}$. of the suspensions and sera were obtained 5 to 7 days after the final injection. In some instances a second course was given (indicated by a subscript 2 after the rabbit number). Only Gram-positive suspensions were used for the injections and analyses.

Agglutinin active against the various suspensions was determined as in (3) by addition of an accurately measured volume of suspension, usually $2.0 \mathrm{ml}$. containing 0.40 to $0.60 \mathrm{mg}$. of $\mathrm{N}$, to 0.5 to $1.0 \mathrm{ml}$. of antiserum at $0^{\circ}$, letting stand in the cold for $48 \mathrm{hrs}$. with occasional stirring, centrifuging in the cold, ${ }^{3}$ washing twice with $3.0 \mathrm{ml}$. of chilled saline, and analyzing the residues for nitrogen by a modification of the micro Kjeldahl method. The increase in nitrogen over that in the

TABLE I

Absence of Type II Specific Polysaccharide in Pneumococcus II $R$ (Dawson S), Strain D 39

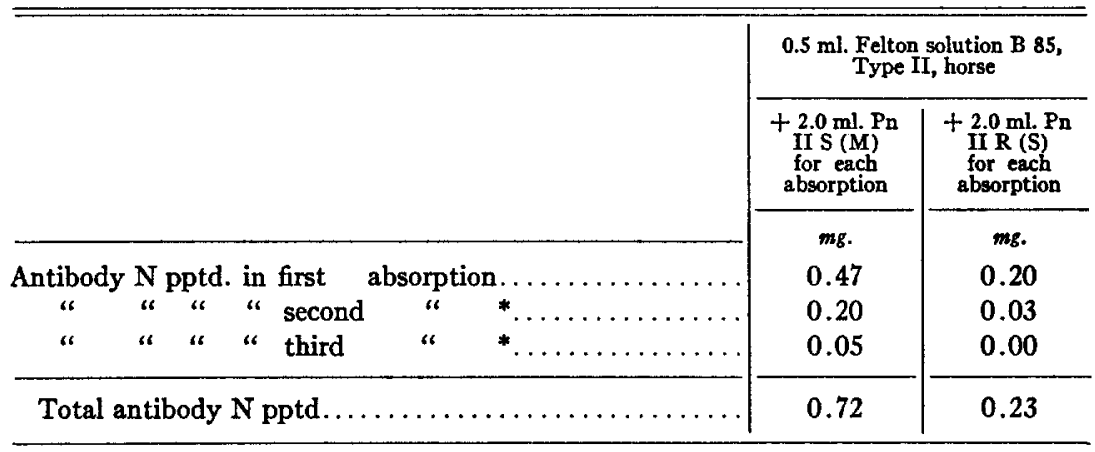

* Corrected for aliquot portion of supernatant used.

volume of suspension used represented the agglutinin nitrogen removed in the first absorption. In all cases the analysis was repeated with aliquot portions of the supernatant from the first centrifugation, and any additional amounts of agglutinin nitrogen taken out were added to the first result, correcting for the aliquot taken. In some instances third, fourth, and fifth absorptions were necessary and even then sera were not always completely freed from agglutinins. Alkalinity of the sera was not the only factor involved in this slow removal of agglutinins from certain sera, but more consistent results could apparently be obtained after adjustment of $\mathrm{pH}$ to 6.5 to 7 . It was usually found advisable to centrifuge all supernatants a second time in order to throw down any pneumococci carried along. The number of tubes and labor involved in doing this could be

- A refrigerated centrifuge manufactured by the International Equipment Company, Boston, Massachusetts, was used. 
held to a minimum by adding the first and second washings (and preferably a third) successively to the tube in which the original supernatant had been recentrifuged, centrifuging again after each addition, and combining any residue with the main portion of agglutinated cells.

Anti- $\mathrm{C}$ was determined as in (6) by addition of a moderate excess of $\mathrm{C}$ substance, preferably prepared from a pneumococcus type different from that with which the rabbit furnishing the antiserum was injected. This was, however, immaterial if either the $\mathrm{C}$ used for the analysis or the culture used for immunization contained no type specific polysaccharide. The tubes were allowed to stand at $0^{\circ} \mathrm{C}$. for 48 hours and nitrogen estimations were made on the washed precipitates. $\mathrm{C}$ substance nitrogen in the precipitates was deducted.

In Table $\mathrm{I}$ are given data on the absorption of Type II antipneumococcus Felton solution (7) with Pn II S (M) and Pn II R (S) suspensions. Absence of Type II specific polysaccharide in the $R$ (S) suspension is shown by the removal of far less antibody than is taken out by Pn II M.

Analytical data on the amounts of agglutinin in the various antisera for the different types of Pn suspension are summarized in Table II. Estimations of anti-C precipitin in a number of the sera are also given. Data are also included on the amount of agglutinin nitrogen removed by several of the suspensions from a mixed Type I and II antipneumococcus horse serum.

\section{DISCUSSION}

In the second paper of this series (4) it was shown that the quantitative, absolute agglutinin method (3) provided a means for detection of the presence or absence of an antigenic component in a bacterial strain. This was illustrated by showing the absence of the specific polysaccharide of Type I pneumococcus (S I) in the R (S) strain used, and the presence of S III in an incompletely degraded Pn III R. The I R (S) strain employed in the present studies was the same as that used in the earlier work. Evidence for the absence of S II in the Pn II $\mathrm{R}$ strain used is given in Table I. It will be noted that antibody absorption with this strain comes to an end with the removal of only one-third as much antibody as is taken out by Pn II in the S (M) phase.

Analytical data on rabbit antisera to formalin-killed, heat-killed, and acid-killed Types I and II R (S) pneumococci are given in Table 
II. It is apparent that the principal antibody in a number of these sera is anti-C, and that in such sera antibodies to pneumococcus cell proteins play a minor rôle. The anti-C content in the I R FK series

TABLE II

Antibody Removed from Antipneumococcus $R(S)$ Rabbit Sera by Homologous and Heterologous $P n R(S)$ Suspensions and by $C$ Substance

\begin{tabular}{|c|c|c|c|c|c|c|c|c|}
\hline \multirow{3}{*}{ Rabbit serum No. } & \multirow{3}{*}{$\begin{array}{c}\text { Pn antigen } \\
\text { injected }\end{array}$} & \multicolumn{7}{|c|}{ Antibody nitrogen removed per ml. serum } \\
\hline & & \multicolumn{6}{|c|}{ by pneumococcus $R$ (S) } & \multirow{2}{*}{ by $\mathrm{C}$} \\
\hline & & $\begin{array}{c}\text { Type I I } \\
\text { FK }\end{array}$ & $\mid \begin{array}{c}\text { Type I } \\
\text { HK }\end{array}$ & $\underset{\text { Ty I }}{\text { Type I }}$ & $\begin{array}{c}\text { Type II } \\
\text { FK }\end{array}$ & $\begin{array}{c}\text { Type II } \\
\text { HK }\end{array}$ & Type II & \\
\hline & & $m g$. & $m g$. & $m g$. & mg. & $m g$. & $m g$. & $m g$. \\
\hline 3.35 & I R FK & 0.60 & & 0.46 & 0.57 & & & $>0.52^{*}$ \\
\hline 3.37 & " & $0.40 t$ & & 0.34 & & & & $>0.32^{*}$ \\
\hline 3.43 & " & $0.30+$ & & 0.28 & & & & 0.23 \\
\hline 4.48 & I R HK & & 0.26 & & & 0.27 & & \\
\hline $3.30_{1}$ & I R AK & 0.15 & & 0.14 & & & & 0.06 \\
\hline $3.30_{2}$ & “ & $0.32 \dagger$ & 0.38 & 0.39 & $0.49 \dagger ?$ & & 0.35 & 0.07 \\
\hline 3.31 & “ & $0.18 \ddagger$ & & 0.13 & & & & $>0.13^{*}$ \\
\hline $3.42_{1}$ & “ & & & 0.13 & & & & $>0.15^{*}$ \\
\hline $3.42_{2}$ & “ & & & & & & $0.38 \dagger$ & $0.01 \ddagger$ \\
\hline 1.76 & II R FK & 0.70 & 0.30 & 0.26 & $1.23 \dagger$ & 0.64 & 0.37 & \\
\hline 3.39 & " & $0.16 \ddagger$ & $0.27 \dagger$ & & $0.44 \dagger$ & $0.70+?$ & & \\
\hline 3.32 & II R AK & 0.388 & $0.66 \dagger$ & & $0.48 \dagger$ & $0.66 \dagger$ & & $0.02 \ddagger$ \\
\hline \multicolumn{9}{|l|}{$\underset{\text { serum }}{\text { Anti-Pn I, II horse }}$} \\
\hline 702 & $\mathrm{I}, \mathrm{II} S(\mathrm{M})$ & 0.39 & $0.30 \dagger$ & & 0.39 & $0.27 \|$ & & \\
\hline
\end{tabular}

$\mathrm{FK}=$ formalin-killed, $\mathrm{HK}=$ heat-killed, $\mathrm{AK}=$ acid-killed.

* Redeterminations after 3 years gave $0.49,0.26,0.05,0.06$, respectively, for these sera. Serum 3.37 gave $0.27 \mathrm{mg}$. N with C I, $0.25 \mathrm{mg}$. with C II. The original analysis was made with C III.

$\uparrow$ Sera not entirely exhausted after 3 to 4 absorptions.

$\ddagger$ Analyzed 3 years after other values were obtained.

§ Supernatant gave $0.23 \mathrm{mg}$. more antibody $\mathrm{N}$ in 2 absorptions with $\mathrm{Pn} \mathrm{I}$ R HK.

|| Supernatant gave $0.11 \mathrm{mg}$. more antibody $\mathrm{N}$ in 1 absorption with Pn I R FK.

was particularly high, but whether or not the formalinized suspension is unusually well adapted to the production of this antibody cannot be stated on the basis of the small experimental material. 
It is shown in a footnote to the table that the amount of anti-C found in serum 3.37 was the same whether the $C$ used as reagent was derived from Type I or Type II Pn. The quantitative data accordingly support the conclusion of Tillett, Goebel, and Avery (5) that the same $\mathrm{C}$ substance is produced throughout the pneumococcus group.

It will be noted that, in general, the acid-killed suspensions removed less antibody from the various sera than did the heat-killed or formalin-killed suspensions of the same type. This is somewhat unexpected, as the acid-killed suspensions were used both as antigens and absorbents in the hope that $\mathrm{Pn}$, killed by the relatively mild exposure to buffer at $\mathrm{pH} \mathrm{4,} \mathrm{near} \mathrm{the} \mathrm{isoelectric} \mathrm{points} \mathrm{of} \mathrm{the} \mathrm{cell} \mathrm{pro-}$ teins, would prove the best of the series. Possibly the ease with which the AK cells become Gram-negative ( $c f$. Dubos (8)) is a factor, although only Gram-positive AK suspensions were used for the immunizations and analyses.

In general, Types I and II Pn suspensions which had been treated in the same way removed the same amount of antibody from a given antiserum to Type I or Type II Pn R (S). Only in the two Pn II R FK antisera was there any evidence of type specificity. Since it has been shown (Table I) that the Pn II strain used contained no type specific polysaccharide, and that C I and C II precipitate the same amount of antibody, it is possible that formalin treatment of the Pn II R (S) cells stabilizes a minor type specific antigen. The Pn I R FK antisera showed no such type difference, but in these sera there was little antiprotein and almost all of the antibody was anti-C, which appears to be equally reactive with C I, C II, or C III. The data, therefore, support quantitatively the conclusion of Avery and his coworkers (9) that pneumococcus protein is the same throughout this group of microorganisms, except that in the Pn II R FK cells, at any rate, an additional minor type specific antigen is indicated.

\section{SUMMARY}

1. The quantitative, absolute method of agglutinin estimation is extended to the reaction between Types I and II pneumococcus R (S) suspensions prepared in various ways and antisera from rabbits injected with these cells. 
BACTERIAL AGGLUTINATION. IV

2. Quantitative estimations of the amount of antibody to pneumococcus $\mathrm{C}$ substance are also given.

3. The significance of the data is discussed.

\section{BIBLIOGRAPHY}

1. Dawson, M. H., J. Path. and Bact., 1934, 39, 323.

2. Tillett, W. S., J. Exp. Med., 1927, 46, 343; 1928, 48, 791.

3. Heidelberger, M., and Kabat, E. A., Proc. Soc. Exp. Biol. and Med., 1934, 31, 595; J.Exp.Med., 1934,60, 643.

4. Heidelberger, M., and Kabat, E. A., J. Exp. Med., 1936, 63, 737.

5. Tillett, W. S., Goebel, W. F., and Avery, O. T., J. Exp. Med., 1930, 62, 896. Heidelberger, M., and Kendall, F. E., J. Exp. Med., 1931, 63, 625.

6. Heidelberger, M., and Kendall, F. E., J. Exp. Med., 1935, 61, 559; and earlier papers.

7. Felton, L. D., J. Infect. Dis., 1928, 42, 248; and earlier papers.

8. Dubos, R. J., J. Exp. Med., 1937, 66, 101, 113.

9. Avery, O. T., and Heidelberger, M., J. Exp. Med., 1923, 38, 81; 1925, 42, 367. Avery, O. T., and Morgan, H. J., J. Exp. Med., 1925, 42, 347. 